2016

\title{
The Duty of Corporate Directors to Tie Executive Compensation to the Long-Term Sustainability of the Firm
}

\author{
Alberto Salazar \\ Carleton University, Alberto.Salazar@carleton.ca \\ Muthana Mohamed \\ CarletonUniversity, muthanamohamedmohame@cmail.carleton.ca
}

Follow this and additional works at: http://digitalcommons.osgoode.yorku.ca/olsrps

Part of the Business Administration, Management, and Operations Commons, Business Organizations Law Commons, and the Organizations Law Commons

\section{Recommended Citation}

Salazar, Alberto and Mohamed, Muthana, "The Duty of Corporate Directors to Tie Executive Compensation to the Long-Term Sustainability of the Firm" (2016). Osgoode Legal Studies Research Paper Series. 141.

http://digitalcommons.osgoode.yorku.ca/olsrps/141 


\title{
OSGOODE HALL LAW SCHOOL \\ LEGAL STUDIES RESEARCH PAPER SERIES
}

\section{The Duty of Corporate Directors to Tie Executive Compensation to the Long-Term Sustainability of the Firm}

\author{
Alberto Salazar \\ Muthana Mohamed
}

This paper can be downloaded free of charge from: http://ssrn.com/abstract=2701455

Further information and a collection of publications from the Osgoode Hall Law School Legal Studies Research Paper Series can be found at:

http://www.ssrn.com/link/Osgoode-Hall-LEG.html

\section{Editors:}

Editor-in-Chief: Carys J. Craig (Associate Dean of Research \& Institutional Relations and Associate Professor, Osgoode Hall Law School, York University, Toronto)

Production Editor: Kiana Blake (Osgoode Hall Law School, York University, Toronto) 
Osgoode Legal Studies Research Paper No. 20

Vol. 12/ Issue. 4/ (2016)

\title{
The Duty of Corporate Directors to Tie Executive Compensation to the Long-Term Sustainability of the Firm
}

\author{
Alberto Salazar \\ Muthana Mohamed
}

\begin{abstract}
:
Executive compensation is said to be for performance and, in liberal market economies, the board of directors along with compensation committees have largely been in charge of safeguarding pay for performance. This executive compensation system is legally protected by the business judgment rule (a strong judicial deference) and has recently been supplemented with shareholders' 'say on pay'. Further legal or government intervention has been deemed unnecessary. However, such system has resulted in extremely excessive executive compensation, outrageous pay disparities between executives and workers, poor or short-term performance, recurrent corporate failures and economic recession. This paper explores the need for a stronger legal intervention and argues that directors, in exercising their fiduciary duties, should be legally required to tie executive compensation to the long-term sustainability of the firm that in turn requires the use of executive pay to promote not only sustained growth and long-term shareholder value but also steady improvements in the interests of multiple stakeholders involved in the long-term success of the company, notably employees. It is further argued that, in liberal market economies, employees' 'say on pay' should be considered as it is crucial to allow employees to communicate their interests in order both to incorporate them in the metric of long-term firm sustainability and to counter the likely opposition from short-term oriented shareholders and self-serving directors and officers. This proposal will contribute to avoiding excessive pay and short-termism and to promoting long-term firm performance, which will ultimately protect shareholders and employees' interest in job security, fair and sustainable wages and secured pension while creating more stable economies and avoiding citizens subsidizing periodic corporate failures, excessive executive pay and the wealth accumulation plans of an elite shareholder class. The paper briefly analyzes whether directors have a duty to tie executive pay to long-term performance in the US and Canada and develops the argument building on the lessons that can be drawn from the 2009 German VorstAG (the Act on the Appropriateness of Management Board Remuneration) and the 2015 German Corporate Governance Code.
\end{abstract}

\section{Keywords:}

Pay for long-term performance, executive compensation, long-term sustainability of the firm, fiduciary duties of directors, Germany's 2009 Act on the Appropriateness of Board Remuneration, Dodd-Frank Act, US, Canada.

\section{Author(s):}

Alberto Salazar

Carleton University

E: AlbertoSalazar@CUNET.CARLETON.CA
Muthana Mohamed

Osgoode Hall Law School

E: muthanamohamedmohame@cmail.carleton.ca 


\title{
THE DUTY OF CORPORATE DIRECTORS TO TIE EXECUTIVE COMPENSATION TO THE LONG-TERM SUSTAINABILITY OF THE FIRM
}

\begin{abstract}
Alberto Salazar ${ }^{1}$ and Muthana Mohamed ${ }^{2}$
ABSTRACT

Executive compensation is said to be for performance and, in liberal market economies, the board of directors along with compensation committees have largely been in charge of safeguarding pay for performance. This executive compensation system is legally protected by the business judgment rule (a strong judicial deference) and has recently been supplemented with shareholders' 'say on pay'. Further legal or government intervention has been deemed unnecessary. However, such system has resulted in extremely excessive executive compensation, outrageous pay disparities between executives and workers, poor or short-term performance, recurrent corporate failures and economic recession. This paper explores the need for a stronger legal intervention and argues that directors, in exercising their fiduciary duties, should be legally required to tie executive compensation to the long-term sustainability of the firm that in turn requires the use of executive pay to promote not only sustained growth and long-term shareholder value but also steady improvements in the interests of multiple stakeholders involved in the longterm success of the company, notably employees. It is further argued that, in liberal market economies, employees' 'say on pay' should be considered as it is crucial to allow employees to communicate their interests in order both to incorporate them in the metric of long-term firm sustainability and to counter the likely opposition from short-term oriented shareholders and selfserving directors and officers. This proposal will contribute to avoiding excessive pay and shorttermism and to promoting long-term firm performance, which will ultimately protect shareholders and employees' interest in job security, fair and sustainable wages and secured pension while creating more stable economies and avoiding citizens subsidizing periodic corporate failures, excessive executive pay and the wealth accumulation plans of an elite shareholder class. The paper briefly analyzes whether directors have a duty to tie executive pay to long-term performance in the US and Canada and develops the argument building on the lessons that can be drawn from the 2009 German VorstAG (the "Act on the Appropriateness of Management Board Remuneration) and the 2015 German Corporate Governance Code.
\end{abstract}

\section{INTRODUCTION}

\footnotetext{
${ }^{1}$ Assistant Professor, Department of Law, Carleton University (Ottawa, Canada). PhD (Osgoode Hall Law School, York University), MacArthur Fellow (University of Oxford, UK), CAPORDE fellow (University of Cambridge, UK), email: Alberto.Salazar@carleton.ca. The views expressed here, along with any mistakes, are the responsibility of the authors.

${ }^{2}$ J.D candidate at Osgoode Hall Law School, York University. He previously attended Carleton University, where he graduated with a B.A Honours in Law and Legal Studies.
} 
Ideas on how to reform executive compensation schemes in the United States and Canada have always been pertinent issues for discussions regarding corporate governance in North America, and have become even more pertinent and relevant since the 2008 financial crisis and recent discussions on wealth inequality. Recent economic troubles in Canada and statistics on historical rates of wealth inequality in the United States have also compounded these discussions. A common and well-accepted guiding principle within executive compensation theories is that the compensation paid to executives should be rigidly tied to the long-term sustainability of the firm. The intension of this approach is to encourage long-term oriented thinking and decision making which does not allow much room for excessive risk taking and a lack of sustainability which has characterized the conduct of some industries with excessive executive compensation such as the financial industry in the United States. However, the reality of executive compensation too often diverges from this principle.

This essay explores the legal and regulatory avenues which could be utilized to enforce more reasonable and sustainable executive compensation regimes in North American corporations. Specifically, it argues that directors, in exercising their fiduciary duties, should be legally required to tie executive compensation to the long-term sustainability of the firm. In so doing, directors may be required to use of executive pay to promote not only sustained growth and long-term shareholder value but also steady improvements in the interests of multiple stakeholders involved in the long-term success of the company, notably employees. It is further argued that, in liberal market economies, employees' 'say on pay' should be considered as it is crucial to allow employees to communicate their interests in order both to incorporate them in the metric of longterm firm sustainability and to counter the likely opposition from short-term oriented shareholders and self-serving directors and officers. 
Particular attention will be paid to the example posed by the German model of compensation regulation and the lessons that can be extracted from it for application in liberal market economies such as the US and Canada. The German example, specifically the VorstAG law of 2009, provides an example of what an expansion of legal liability upon directors to ensure reasonable and responsible remuneration practices would look like if applied in a North American context. A central idea this essay will examine is that the VorstAG's expansion of regulation surrounding the substance of executive compensation. This discussion highlights the imposition of a legal responsibility on directors to ensure "reasonable" compensation is a rule, which would have significant mileage in North America in altering the commitment and conduct of executives to the long-term sustainability of the firm.

This paper will begin by outlining the contemporary nature of disproportionate executive compensation schemes in North America, subsequently situating this discussion across the North American economy as a whole. In order to contextualize notions of executive compensation, a discussion on the theory and soundness of our guiding principle of executive compensation will illuminate the connection between compensation and long-term sustainability. These foundational descriptions and theories will then be followed by a thorough analysis of the German VortAG law and the implications of its institution in North America. This section will also provide a brief review of the legal framework for fiduciary duties of directors and long-term executive pay in the US and Canada. Finally, the essay will propose some ideas for developing a fiduciary duty of directors to tie executive compensation to long-term firm sustainability in liberal market economies and highlight some of the challenges that such reform would face in its possible implementation. 


\section{EXECUTIVE COMPENSATION IN CRISIS}

The current regulatory schemes governing executive compensation in North America are unsustainable and are conducive to unsustainable markets, industries, and the widening of wealth inequality. In Canada, the average CEO in 2014 earned roughly 206 times as much as the average worker while in the United States the average CEO earns roughly 354 times that of the average worker. ${ }^{3}$ Such wildly high compensation rates have two major negative effects within the economy: the incentivization of risky behaviour and the widening of wealth inequality. Both of these negative effects harm the prospects for the average North American to succeed in the economy.

Excessive executive compensation has the effect of incentivizing excessive risk taking behaviour on the part of executives whose compensation is determined using short-term based metrics which do not pay heed to the long-term sustainability of executive action. ${ }^{4}$ This can be seen most poignantly in the example of the U.S financial crisis where the executives of top investment banks as Goldman Sachs and JP Morgan engaged in wildly excessive risk taking by expanding the sub-prime mortgage bubble whose burst, consequently, sparked the 2008 Great Recession. For these companies, the executive compensation structures were such that short-term minded thinking and behaviour was incentivized since short-term increases in the stock price of the firm was the prime metric by which most executive compensation was awarded. ${ }^{5}$ The

\footnotetext{
${ }^{3}$ Canadian CEOs Earn 206 Times as Much as the Average Worker, HUFFINGTON POST CANADA, September 2, 2014, http://www.huffingtonpost.ca/2014/10/02/ceo-worker-pay-ratio-canada n 5 5921002.html

${ }^{4}$ Lucian A Bebchuk \& Holger Spamann, Regulating Bankers' Pay, 98 (2) GEORGETOWN LAW JOURNAL 247 (2010).

${ }^{5}$ Lucian A Bebchuk, How to Fix Bankers' Pay, 139 (4) DAEDALUS 2 (2010).
} 
executives of these firms were awarded huge sums of performance pay, yet their performance was only judged based on a short-term basis focused on stock prices. These flawed compensation and incentive structures which rewarded short-term gain without due regard to the long-term sustainability of the company incentivized financial executives on Wall Street to take advantage of the housing market and ignite the sub-prime mortgage disaster. ${ }^{6}$ James Bicksler of Rutgers Business School directly holds the compensation structures of investment banks as one of the prime causes of the Great Recession, suggesting that executive compensation prior to the crash of 2008 was not sufficiently linked to the actual long-term value of the company's stock. In asserting this, Bicksler cites the CEO of Merrill Lynch who in 2006 received 91 million dollars in compensation because of increases in short-term revenues but in the next year was forced to resign after billions in losses from subprime mortgages. ${ }^{7}$ In addition, the CEO left the company with a 160 million dollar retirement package in stocks and benefits, which further illustrates the degree of backwardness that modern executive compensation and incentive structures intrinsically possess. In fact, many executives who were excessively compensated for their role in artificially inflating the housing markets were able to dispose of their shares and evade the impact that the recession would have on their wealth. Consequently, executives in North America are not sufficiently held accountable to the long-term outcomes of their business practices in such a manner that would encourage the sustainable development of their companies. ${ }^{8}$ Instead they are shielded from the long-term consequences of their decisions and they are incentivized to base their practices on goals whose interests and profits are primarily

\footnotetext{
${ }^{6}$ James L Bicksler, The Subprime Mortgage Debacle and its Linkages to Corporate Governance, INTERNATIONAL JOURNAL OF DISCLOSURE AND GOVERNANCE 5 (2008).

${ }^{7} I d$.

${ }^{8}$ Bebchuk, supra note 2 at 2.
} 
short-term oriented.. ${ }^{9}$ Allowing such a compensation regime to operate without restraint is thus risking the economic stability and sustainability of North American economies, and through the dynamics of international markets, the sustainability of international markets as well.

Although the Canadian corporate world may not have examples which exemplify the backwardness of compensation structures to the degree that the aforementioned example of Wall Street and its role in the 2008 recession does, there are flaws in Canada's compensation regime which exemplify the manner in which excessive executive compensation affects income inequality. A 2012 report by the Canadian Centre for Policy Alternatives reports that income inequality in Canada is rising at a pace faster than in the United States and is at least in part attributable to unsustainable and excessive executive compensation structures in Canada. This subsequently increases the concentration of wealth in society and exacerbates the difference between executive and the pay of average workers. ${ }^{10}$ The effects of troubling rates of wealth inequality include social unrest, rising crime rates, and a lack of public trust in institutions and the government. ${ }^{11}$

The solution to fixing an executive compensation regime which rewards short-term thinking and increases in stock prices, and shields executives from the long-term consequences of their decisions is seemingly simple. It requires abiding by the guiding principle mentioned in the introduction of this essay which is to link the long-term consequences of executive decisions to the personal wealth of these executives. This practices needs to ensure that the executives do

\footnotetext{
${ }^{10}$ Hugh Mackenzie, All in a Day's Work? CEO Pay in Canada, Canadian Centre for Policy Alternatives (January 2014)available at: https://www.policyalternatives.ca/sites/default/files/uploads/publications/National\%200ffice/2014/01/All_in_a_Day s_Work_CEO \%20Pay.pdf

${ }^{11} I d$ at 6.
} 
not receive compensation premised on short-term increases in stock price or compensation that is bloated thus contributing to further wealth inequality. Many theorists of executive compensation agree that compensation should revolve around notions of long-term performance in order to reduce risk taking on the part of executives who judge success (and thus their compensation) on the short-term performance of the firm's stock value. ${ }^{12}$ This flawed focus on a firm's short-term stock price is detrimental and is conducive to reckless risk-taking. As Roger Martin of the University of Toronto argues, it rewards executives on a manufactured value, that of the stock price rather than the value of the company in the "real market" which is "the market where revenues are earned expenses paid and real dollars of profit show up on the bottom line."13 Success in this real market necessitates a long-term outlook and sustainable business decisions and often reflect themselves in the long-term value of the stock rather than its short term value. ${ }^{14}$

Reforming executive pay to incentivize a focus on the long-term performance of the firm, and thus its success in the real economy as opposed to the stock market- though success therein often still translates to success in the stock market — requires reducing excessive risk taking. This reduction can be realized by ensuring that executives are incentivized to do what is best for their personal wealth, the fate of which would be inexorably linked to the real success of the company in the long-term. This principle also has benefits with regards to encouraging corporate and industrial order as incentivizing long-term oriented thinking aligns executive and shareholder interests, thus helping to ensure that the executive boards of companies fulfill their duties under those whom they operate the corporation for, shareholders and non-shareholder

\footnotetext{
${ }^{12}$ Bebchuk, supra note 2 at 5-6.

${ }^{13}$ Martin Rogers, Undermining Staying Power: The Role of Unhelpful Management Theories, ROTMAN MAGAZINE, 6, (2009). ${ }^{14} I d$.
} 
stakeholders. Furthermore, following this principle of executive compensation has beneficial impacts with regards to corporate social responsibility. Studies show that there is a positive correlation between long-term performance compensation and the firm's sensitivities to their greater impacts on the environment. ${ }^{15}$ One of the reasons for this positive correlation is because incentives which focus on long-term outcomes necessitate, on the part of the firm's executives, a commitment to producing quality products and a proactive environmental stance which increases the likelihood of the firm's long-term sustainability and profitability.

The question now turns to the main objective of this essay which is to analyze the reformation of executive compensation through a regulatory based expansion of legal burdens upon executives to institute long-term oriented compensation. The two main parts of this reform structure are the utilization of regulatory principles and legal frameworks to force directors to award long-term oriented and sustainable executive compensation. These principles and structures will pay particular attention to the German VorstAG regulatory model and will address how a legal duty to force executives to tie the long-term sustainability of their firm to their executive compensation would operate in liberal market economies like the US and Canada. Through the reformation of the regulatory structure of executive compensation laws, directors' and officers' fiduciary duty will also be strengthened and forced to be exercised more responsibly since there would be an increase of legal liability for company directors should they award compensation contrary to the company's long-term interest. ${ }^{16}$ These reforms thus force

\footnotetext{
${ }^{15}$ L. S. Mahoney, \& Linda Thorne, Corporate Social Responsibility and Long-Term Compensation: Evidence from Canada, 57:3JOURNAL OF BUSINESS ETHICS 241(2005).

${ }^{16}$ Courts in the U.S and Canada have found that excessive and unreasonable executive compensation could potentially violate an executive's or directors fiduciary duty to shareholders. See ThomasS. Randall \& Harwell Wells, Executive Compensation in the Courts: Board Capture, Optimal Contracting, and Officer's Fiduciary Duties, 95MINNESOTA LAW REVIEW 846(2011); and Unique Broadband Systems Inc. (Re), 2013 ONSC 2953; and Koehnen, Oppression and Related Remedies
} 
directors and executives to award compensation tied to the company's long-term interest.

Without reformation to the current executive compensation practices, the correlation between short-term oriented praxis of business strategies and potential harm to corporations and the economy as a whole, will be perpetuated due to this lack of accountability from the decisionmakers.

\section{THE DUTY OF DIRECTORS TO TIE EXECUTIVE COMPENSATION TO THE LONG- TERM SUSTAINABILITY OF THE FIRM IN GERMANY}

Germany has recently introduced legal reforms to require the tying of executive compensation to the long-term sustainability of the firm while setting standards that this compensation must meet according to the new regulatory framework. ${ }^{17}$ The Vorstandsvergütungsangemessenheitsgesetz ("VorstAG"), as translated to English, the Act on the Appropriateness of Management Board Remuneration, took effect in August 2009 and applies to all publically-traded German companies. ${ }^{18}$ It was aimed at improving transparency within the German corporate world and orienting executive compensation to focus on long-term interests instead of merely short-term gains, and thus increasing the trust that investors have of German firms. ${ }^{19}$ It was meant to alter what German legislators thought to be fallacious corporate incentives which they considered to have abetted the 2008 financial crisis. ${ }^{20}$ These reforms were touted as much needed by German

\footnotetext{
${ }^{17}$ Rainald Thannisch, Reorienting Management Remuneration Towards Sustainability: Lessons From Germany in THE SUSTAINABLE COMPANY: A NEW APPROACH TO CORPORATE GOVERNANCE 131 (Sigurt Vitols \& Norbert Kluge, eds., 2011).

${ }^{18}$ Emilie Mathieu, Beyond Wall Street: Germany, the United States, and Executive Compensation, 38:2 BROOKLYN JOURNAL OF INTERNATIONAL LAW 579, 583 (2013).

${ }^{19}$ Id. at 607; Germany Introduces New Rules on Management Board Compensation, BRIEFING, Freshfield Bruckhaus Deringer, London, UK, August 2009, at 1.

${ }^{20}$ Michael Kling Marburg, The Appropriateness of Directors' Compensation under Para. 87 of the German Stock Corporation Act 2009, DEUTSCHE ZEITSCHRIFT FÜR WIRTSCHAFTS- UND INSOLVENZRECHT, 5 (2010).
} 
Chancellor Angela Merkel after the financial crisis in order to reform the corporate governance code which in Germany has traditionally been less comprehensive than American corporate governance measures. ${ }^{21}$ It was thus passed with strong objections from the German corporate world, a bloc that traditionally supports Chancellor Merkel, which indicates the degree of necessity that German lawmakers believed the VorstAG had. ${ }^{22}$ Michael Kling Marburg writes that the VorstAG was a direct response to the 2008 financial crisis, where it was viewed that companies "had been too focused on reaching short-term goals such as increased turnover figures or raising stock prices by arbitrary deadlines."23

This new regulation attempts to incentivize long-term oriented thinking primarily by reforming the obligations that the Supervisory Board has with regards to compensation, mandating it to act as a stronger check on the management board of the firm in order to ensure the paying of reasonable compensation. ${ }^{24}$ This helps to ensure that the supervisory board is able to temper executive compensation by ensuring that the long-term interests of the firm are what inform the compensation packages awarded to executives through the increased obligations the regulations place on directors. The obligations that the VorstAG institutes to realize this goal include such measures as "say on pay" requirements, and requirements for appropriate and proportional executive compensation. The specific reforms of the VorstAG will now be thoroughly detailed and then analyzed for their potential application in the North American setting.

\footnotetext{
${ }^{21}$ Mathieu, supra note 18, at 583.

${ }^{22}$ Id. at 584; Letter from Berlin: Merkel Takes on the Fat Cats, SPIEGEL ONLINE INT'L (2007), available at: http:// www.spiegel.de/international/germany/0,1518,522480,00.html.

${ }^{23}$ Marburg, supra note 20, at 5.

${ }^{24}$ Mathieu, supra note 18 , at 616.
} 
There are three key ways that the VorstAG ties the long-term sustainability of the firm to the compensation paid to executives. The first is perhaps the most often cited and praised reform, which requires that the executive compensation awarded by the supervisory board be appropriate. The criteria for determining the appropriateness of compensation are the actual responsibilities and performance of the executives and the company's current financial situation. ${ }^{25}$ The compensation must be proportional to the executive's duties and cannot be unreasonable in light of the company's "general economic situation". ${ }^{26}$ This rule also requires that the compensation accords with industry standards and that the compensation in the case of publically listed companies should be oriented towards the long-term sustainability of the firm. ${ }^{27}$ The law itself specifically states that "the remuneration system of listed companies shall be aimed at the company's sustainable development "and the "calculation basis of variable remuneration components should therefore be several years long." 28 The Supervisory Board is even allowed to reduce executive remuneration if the situation of the company deteriorates over time. ${ }^{29}$ The VorstAG amended Section 87 of the German Stock Corporation Act (Aktiengesetz; "AktG") in order to specifically define the notion of “appropriateness" of management board compensation. By virtue of the VorstAG, Section 87 of the $A k t G$ now reads as follows:

\section{$\S 87$ Principles Governing Remuneration of Members of the Management Board}

(1) The supervisory board shall, in determining the aggregate remuneration of any member of the management board (salary, profit participation, reimbursement of expenses, insurance premiums, commissions, incentive-based compensation promises such as subscription rights and additional benefits of any kind), ensure that such aggregate

\footnotetext{
${ }^{25}$ German Stock Corporation Act 2013 (Aktiengesetz), s.87. See also Jean J. du Plessis \& Ingo Saenger The General Meeting and the Management Board as Company Organs in Jean J. Du Plessis, Großfeld, B., Luttermann, C., Saenger, I., Sandrock, O. \& Casper, M., GERMAN CORPORATE GOVERNANCE IN INTERNATIONAL AND EUROPEAN CONTEXT 70 (2012).

${ }^{26}$ Plessis and Saenger, id.

27 Thannisch, supra note 12 at 131.

28 Aktiengestz, s.87 (1), supra note 23.

${ }^{29}$ Aktiengestz, s.87 (2), supra note 23.
} 
remuneration bears a reasonable relationship to the duties and performance of such member as well as the condition of the company and that it does not exceed standard remuneration without any particular reasons. The remuneration system of listed companies shall be aimed at the company's sustainable development. The calculation basis of variable remuneration components should therefore be several years long; in case of extraordinary developments, the supervisory board shall agree on a possibility of remuneration limitation. Sentence 1 shall apply analogously to pensions, payments to surviving dependents and similar payments.

(2) If the situation of the company deteriorates after the determination so that a continued payment of remuneration under (1) would be unreasonable for the company, the supervisory board or, in case of $\S 85$ (3), the court upon petition of the supervisory board shall reduce remuneration to a reasonable level. Pensions, payments to surviving dependents and similar payments may only be reduced pursuant to sentence 1 within the first three years after resignation from the company. Such reduction shall not affect the other terms of the contract of employment. The member of the management board may terminate, however, his contract of employment as of the end of the next calendar quarter upon giving six weeks' notice. ${ }^{30}$

The Supervisory Board members are subject to liability if they fail to set a compensation that is not consistent with the sustainability of the company. Section 116 of the AktG states that the members of the Supervisory Board "are in particular liable for damages if they determine unreasonable remuneration" making clear reference to s. 87 (1) of the $A k t G .{ }^{31}$ Even members of the Supervisory Board, when promised performance-related compensation, must receive compensation that "shall be oriented toward sustainable growth of the enterprise." 32

\footnotetext{
${ }^{30}$ German Stock Corporation Act (Aktiengesetz) English translation as at September 18, 2013, Norton Rose Fulbright, (2013), available at: http://www.nortonrosefulbright.com/files/german-stock-corporation-act-109100.pdf. See also Jones Day, New developments in management board compensation (November 8 2010), online:http://www.lexology.com/library/detail.aspx?g=6041532c-d4fb-4276-87e4-76751647888d; Marc Eulerich. \&Patrick Velte, Nachhaltigkeit und Transparenz der Vorstandsvergütung. Eine empirische Untersuchung im DAX30 unter besonderer Berücksichtigung der Bemessungsgrundlagen der variablen Vergütungsanteile,ZEITSCHRIFT FÜR INTERNATIONALE RECHNUNGSLEGUNG, 8,2, (2013).

${ }^{31}$ German Stock Corporation Act (Aktiengesetz) English translation as at September 18, 2013, Norton Rose Fulbright (2013), available at: http://www.nortonrosefulbright.com/files/german-stock-corporation-act-109100.pdf.

32 The Deutscher Corporate Governance Kodex, THE GERMAN CORPORATE GOVERNANCE CODE, section 5.4.6 at 12.(2015).
} 
It is important to note that the August 2009 VorstAG, the Act on the Appropriateness of Management Board Remuneration, appears to have been a more comprehensive implementation of earlier executive compensation recommendations issued by the European Commission. The latter issued the Commission Recommendation on Remuneration Policies in the Financial Services Sector, dated 30 April 2009, ${ }^{33}$ inviting Member States to take necessary measures to promote the application of its executive compensation recommendations by 31 December $2009 .{ }^{34}$ The European Commission recommended that financial institutions adopt executive remuneration policies that are aligned with the long-term interest and sustainable growth of companies: ${ }^{35}$

3.2. Remuneration policy should be in line with the business strategy, objectives, values and long-term interests of the financial undertaking, such as sustainable growth prospects, and be consistent with the principles relating to the protection of clients and investors in the course of services provided. ${ }^{36}$

The Deutscher Corporate Governance Kodex, the German Corporate Governance Code (hereafter known as the Code), as amended and published in the Federal Gazette on 12 June 2015, also indicates that Supervisory Board determines the compensation of Management Board members and the criteria for determining the appropriateness of a compensation includes the sustainable performance and outlook of the company. This concern for the sustainability of the firm is consistent with the general purpose of the Code, namely, to clarify the obligations of the

\footnotetext{
${ }^{33}$ Commission Recommendation on Remuneration Policies in the Financial Services Sector, (20091384, EC)April 30, 2009, OFFICIAL JOURNAL OF THE EUROPEAN UNION 15.5.2009, available at http://eur-lex.europa.eu/legalcontent/EN/TXT/PDF/?uri=CELEX:32009H0384\&from=EN.

${ }^{34}$ Commission Recommendation on Remuneration Policies in the Financial Services Sector, 384, (2009), OFFICIAL JOURNAL OF THE EUROPEAN UNION 15.5.2009, Article 13, available at http://eur-lex.europa.eu/legalcontent/EN/TXT/PDF/?uri=CELEX:32009H0384\&from=EN.

${ }_{35}$ Marvin Vesper-Gräske, 'Say on Pay" in Germany: The Regulatory Framework and Empirical Evidence, 14 GERMAN L.J. 749, 755 (2013).

${ }^{36}$ Commission Recommendation on Remuneration Policies in the Financial Services Sector, (2009/384/EC), 30 April 2009, OFFICIAL JOURNAL OF THE EUROPEAN UNION 15.5.2009, at L 120/25, available at http://eurlex.europa.eu/legal-content/EN/TXT/PDF/?uri=CELEX:32009H0384\&from=EN.
} 
Management Board and the Supervisory Board to "ensure the continued existence of the enterprise and its sustainable creation of value in conformity with the principles of the social market economy" ${ }^{37}$ The Supervisory Board is also asked to take into account the future when considering the relationship between the compensation of board members and employees. It is worth noting that by virtue of controlling one third or one half of the seats of the Supervisory Board, ${ }^{38}$ employees exert significance influence on determining the level and sustainability of executive compensation.

The relevant provisions of the Code read as follows:

4.2.2 The full Supervisory Board determines the respective total compensation of the individual Management Board members. If there is a body which deals with Management Board contracts, it submits its proposals to the full Supervisory Board. The full Supervisory Board resolves the Management Board compensation system and reviews it regularly. The total compensation of the individual members of the Management Board is determined by the entire Supervisory Board in plenary session at an appropriate amount based on a performance assessment, taking into consideration any payments by group companies. Criteria for determining the appropriateness of compensation are both the tasks of the individual member of the Management Board, his/her personal performance, the economic situation, the performance and outlook of the enterprise as well as the common level of the compensation taking into account the peer companies and the compensation structure in place in other areas of the company. The Supervisory Board shall consider the relationship between the compensation of the Management Board and that of senior management and the staff overall, particularly in terms of its development over time, whereby the Supervisory Board shall determine how senior managers and the relevant staff are to be differentiated.

...

4.2.3 ... The compensation structure must be oriented toward sustainable growth of the enterprise. The monetary compensation elements shall comprise fixed and variable elements. The Supervisory Board must make sure that the variable compensation elements are in general based on a multi-year assessment. Both positive and negative developments shall be taken into account when determining variable compensation components. All compensation components must be appropriate, both individually and in total, and in particular must not encourage to take unreasonable risks. The amount of compensation shall be capped, both overall and for individual compensation components. The variable compensation components shall be related to demanding, relevant comparison parameters.

\footnotetext{
${ }^{37}$ The Deutscher Corporate Governance Kodex, THE GERMAN CORPORATE GOVERNANCE CODE, June 12, 2015, Introduction at 1.

${ }^{38} I d$.
} 
Changing such performance targets or the comparison parameters retroactively shall be excluded. ...

4.2.5. ... In addition, for financial years starting after 31 December 2013, and for each Management Board member, the compensation report shall present:

- the allocation of fixed compensation, short-term variable compensation and long-term variable compensation for the year under review, broken down into the relevant reference years;.$^{39}$

It is important to note that the Government Commission, Regierungskommission Deutscher develops and review The Code annually. The Commission was introduced by the German Federal Minister of Justice in September 2001, which appoints its members. ${ }^{40}$ The Code presents essential statutory regulations, internationally recognized standards, recommendations and suggestions for the good and responsible governance primarily of listed companies in Germany. ${ }^{41}$ Recommendations are central regulatory components of the Code. Companies can deviate from the recommendations (marked by the use of the word "shall"), but are then obliged to disclose it and to justify the deviations (comply or explain). ${ }^{42}$

The German Sustainability Code (GSC), introduced in 2012, further recommends that companies link executive compensation with sustainability:

Incentive Schemes

8. The company discloses how target agreements and remuneration schemes for executives are also geared to achieving the sustainability goals and how these are geared towards lasting value creation. It discloses the extent to which sustainability performance forms

\footnotetext{
${ }^{39} I d$ at 6-8.

${ }^{40}$ Commission, REGIERUNGSKOMMISSION DEUTSCHER CORPORATE GOVERNANCE KODEX, available at: http://www.dcgk.de/en/commission.html

${ }^{41}$ The Deutscher Corporate Governance Kodex, supra note.

${ }^{42} I d$, Introduction at 2.
} 
part of the evaluation of the top management (board/managing directors) conducted by the monitoring body (supervisory board/advisory board). ${ }^{43}$

Defining long-term firm sustainability is crucial to ascertain the scope of the duty of the Supervisory Board to tie executive compensation to the sustainable growth of enterprises. In expounding on the definition of "sustainability" that informs section 87(1), Marburg writes that the definition comes from European environmental law, and that within the business context it relates to the understanding that corporate executives should not pursue short-term interests and that they should not be rewarded for any short-term benefits that come at the long-term expense of the company. ${ }^{44}$ This understanding of sustainability relies on a conception of steady and planned growth that is not relying on windfall profits or anything equally impermanent and unstable. Thus ex ante prosperity is not necessarily needed to be elemental to executive success in this regard. Planned sustainability will suffice as deserving of adequate compensation..$^{45}$ According to German scholars writing on the VorstAG, when analyzing executive success, the focus on sustainability partly manifests itself through a conception of success that considers the furtherance of "complimentary company business decisions objectives such as safeguarding employment, raising profits and increasing market shares" as objectives deserving of adequate compensation."46

Moreover, it can be argued that the stakeholder orientation of the German corporate governance system along with co-determination favors a conception of long-term firm sustainability that incorporates multiple stakeholders' interest. This is further reinforced by the

\footnotetext{
${ }^{43}$ The German Sustainability Code, Recommendations of the German Council for Sustainable Development, Text no. 41, January 2012, available at http://www.nachhaltigkeitsrat.de/uploads/media/RNE_The_German_Sustainability_Code_GSC_text_No_41_Januar y_2012.pdf.

${ }^{44}$ Marburg, supra note 20, at 23.

${ }^{45} I d$. at 24 .

${ }^{46} I d$. at 10 .
} 
belief that the success and long-term sustainability of companies also depend on the contribution of multiple stakeholders such as employees, customers, creditors and suppliers. The interests of stakeholder are also captured and promoted by sustainability objectives and it is thus reasonable to assume that the assessment of long-term firm sustainability is to be informed by the larger objective of sustainability in Germany. The GSC provides the following definition of sustainability which is at the basis of its recommendation that executive pay should aim to achieve sustainability:

\begin{abstract}
What is sustainability?
"Sustainable development is development that meets the needs of the present without compromising the ability of future generations to meet their own needs. [...] In essence, sustainable development is a process of change in which the exploitation of resources, the direction of investments, the orientation of technological development, and institutional change are all in harmony and enhance both current and future potential to meet human needs and aspirations." Brundtland-Commission 1987. ${ }^{47}$
\end{abstract}

Pay for long-term firm sustainability ties the consequences of executive performance to their personal wealth, thereby encouraging long-term minded thinking. ${ }^{48}$ Compensation packages cannot be structured to be outrageously high, especially in dire economic circumstances, and they cannot be structured to reward or incentivize short-term minded behaviour and excessive risk taking since these are not conducive to a company's sustainable development. Importantly, compensation must be calculated with a mind towards the mitigation of risky executive behaviour and the promotion of sustainable growth. The conception of long-term firm sustainability should inform the use and reform of compensation instruments. The latter are important because they give effect to the principle of appropriate and long-term oriented compensation. Variable compensation

\footnotetext{
${ }^{47}$ The German Sustainability Code, available at http://www.nachhaltigkeitsrat.de/uploads/media/RNE_The_German_Sustainability_Code_GSC_text_No_41_Januar y_2012.pdf

${ }^{48}$ Compensation which incentivizes long-term minded thinking is compensation that is paid over many years and is awarded based on long-term company performance rather than short-term stock increases. See, Bebchuk Lucian A. \&Jesse M. Fried, Paying for Long-Term Performance, 139(4) DAEDALUS(2010).
} 
components, for example, would have to include a long-term assessment base. ${ }^{49}$ This is required so that the long-term effects of corporate decision making can manifest themselves on the salary of executives. According to Victoria Krivogorsky, this focus on sustainability compels the Supervisory Board to ensure that the variable compensation of executives is calculated with "risk" in mind and that the compensation incentivizes long-term sustainability. ${ }^{50}$ She adds that the variable components of the compensation should include one-time and annually payable components linked to business performance as well as the long-term incentives with the mitigation of risk in mind. ${ }^{51}$

In addition to imposing a positive obligation on the Supervisory Board to responsibly award compensation that is reasonable in light of the long-term sustainability of the firm and economic circumstances, this rule also encourages executives and directors to justify executive remuneration in terms of long-term oriented thinking. This encourages the proposal of remuneration that is justifiable and defensible with regards to its effects on long-term sustainability. This shift in approach has the potential to change attitudes and the corporate culture with regards to what is deemed to be appropriate compensation because of the need to frame compensation packages in language that is compatible with principles of "sustainability" enumerated in the VorstAG. This dynamic has already shown some promise in Germany where after the VorstAG was passed, this provision proved initially quite successful in at least introducing a discussion about long-term oriented compensation within corporations. Over seventy per cent of German corporations in the DAX 30, the prime German stock index, included a discussion of the

\footnotetext{
${ }^{49}$ Marc Eulerich \& Patrick Velte, Determinants of Executive Board Remuneration. New Insights from Germany, 11 CORPORATE OWNERSHIP \& CONTROL 96 (2014), available at: http://ssrn.com/abstract=2521023. ${ }^{50}$ VICTORIA KRIVOGORSKY, LAW, CORPORATE GOVERNANCE AND ACCOUNTING: EUROPEAN PERSPECTIVES170 (2011). ${ }^{51} I d$.
} 
VorstAG in their shareholder meetings or proxy statements, and structured their compensation regime in terms emphasizing sustainability and appropriateness. ${ }^{52}$

The second key reform instituted by the VorstAG also relates to the use of claw-backs. In the event that the compensation paid to an executive becomes unsustainable in the future (because of new information emerging or a financial hit to the company), the VorstAG legally requires that courts (upon petition of the supervisory board) exercise claw-back measures to retrieve compensation that was undeservingly paid to an executive. ${ }^{53}$ This practice is regardless of whether or not such a claw-back provision is explicitly in the employment contract. This claw-back provision also applies to executive pensions and payments to dependents within the first three years of the executive leaving the company. Such praxis strongly encourages executives to pay heed to the long-term because it forces them to engage in suitable business decisions that will continue to both maintain a soundness of practice as well as foster future soundness of practices. By facilitating a shift from short-term to long-term mentality of business praxis, executives are forced into the position where they must examine their person wealth and the consequences that their business decisions have both inside and outside of the parameters of their employment with the company.

The third key reform by the VorstAG is the introduction of a non-binding "say on pay vote." In accordance with one of the aims of the VorstAG, which is to strengthen transparency within the executive board room, the VorstAG requires a non-binding "say on pay" vote by the shareholder assembly on the compensation to be awarded.${ }^{54}$ Section 120 of the $A k t G$ indicates

\footnotetext{
${ }^{52}$ Mathieu, supra note, at 622-623.

${ }^{53}$ Aktiengesetz supra note 40 at s.87.

${ }^{54}$ Marin Vesper-Grakse, Say on Pay in Germany: The Regulatory Framework and Empirical Evidence, 14 (7)

GERMAN LAW JOURNAL 749(2013).
} 
that shareholders may have a say on executive compensation decisions but this does not affect the powers of the Supervisory Board to determine the compensation of the Management Board members:

Section120 Ratification of the Acts of Management; Vote on the Compensation Scheme

(4) The shareholders' meeting of a listed company may resolve on the approval of the compensation scheme. The resolution shall not give rise to any rights or obligations; in particular, the obligations of the supervisory board pursuant to $\S 87$ shall remain unaffected. The resolution shall not be voidable pursuant to $\S 243 .{ }^{55}$

Say on pay votes can encourage long-term oriented compensation packages through two routes. Firstly, it requires corporations to justify their compensation packages to shareholders which forces the supervisory board to propose appropriate compensation packages that will be defensible in front of shareholders, ${ }^{56}$ including its consistency with the legally required longterm sustainability of the firm as established by Section 87 of the $A k t G$. Secondly, it allows longterm oriented shareholders, such as pension funds, to voice their opinion regarding compensation and demand compensation that is appropriate given the financial situation of the company and its long-term outlook. ${ }^{57}$ In discussing the "say on pay" provision of the VorstAG, Martin VesperGraske says that it was intended to further fulfill the VorstAG's guiding principle of tying longterm sustainability to executive remuneration. ${ }^{58}$ In these instances the law was designed to

\footnotetext{
${ }^{55}$ German Stock Corporation Act, supra note 40. See, e.g., Brigitte Haar, Executive Compensation under German Corporate Law: Reasonableness, Managerial Incentives and Sustainability in Order to Enhance Optimal Contracting and to Limit Managerial Power in RESEARCH HANDBOOK ON EXECUTIVE PAY (Randall Thomas \& Jennifer Hill, eds., 2012).

${ }^{56}$ Amanda Rineheart, et al.,. Corporate Governance Practices in Germany and the United States, 3 (1) DRAKE MANAGEMENT REVIEW105 (2013).

${ }^{57}$ For a discussion on the potential of institutional investors such as pension funds to compel companies to pay attention to long-term sustainability, see David Hess, Public Pensions and the Promise of Shareholder Activism for the Next Frontier of Corporate Governance: Sustainable Economic Development 2 (2)VIRGINIA LAW AND BUSINESS REVIEW(2007).

${ }^{58}$ Vesper-Graske, supra note 45 at 758.
} 
facilitate the remuneration committee to collectively make a decision, but also force the committee into a position whereby they must suggest compensation that is justifiable to begin with so that the shareholders can be satisfied that the compensation is appropriate. The law is also meant to publicize shareholder denials of executive compensation regimes in order to bring negative publicity, thus encouraging the initial proposal of appropriate compensation that will be approved by shareholders. ${ }^{59}$

All of these new regulations introduced by the VorstAG carry the full strength of the law. Section 116 of the Aktiengesetz, or the German Stock Corporation Act (of which the VorstAG is embedded within) states that the paying of "unreasonable compensation" makes Supervisory Board members liable to damages if they determine unreasonable executive compensation. Setting a legal standard for an appropriate executive remuneration along with a director liability, clawback provisions and non-binding say on pay represent a significant legal intervention to restrain managerial power in deciding executive pay and steer compensation towards the long-term interest of companies. The VorstAG is thus a very serious regulatory framework that alters the duty of directors to their firm and its long-term outlook in a way that is meant to operate that duty more effectively

The VorstAG has had a reasonable amount of success in Germany where corporate conversations about compensation are longer and more in-depth than in the past as executive boards have attempted to propose compensation in line with the requirements of the law. At the very least, they have tried to use the language of "sustainability" in justifying their compensation packages which has the potential to encourage actual compensation structures in line with the

${ }^{59} \mathrm{Id}$ at 765 . 
principles of the VorstAG ${ }^{60}$ Of course, it is still too early to make a judgment regarding whether the VorstAG can be said to have directly contributed to increased sustainability within German companies and the economy, although current indications suggest a positive outcome in this regard. ${ }^{61}$ The VorstAG thus shows that a regulatory model which enshrines certain principles and practices can have significant impact on executive compensation and can therefore stand as a lesson for North American discussions regarding the reforming of executive compensation.

\section{FIDUCIARY DUTIES OF DIRECTORS, EXECUTIVE PAY AND LONG-TERM PERFORMANCE IN THE US AND CANADA}

There is only limited potential for American courts to enforce a duty to pay more reasonable compensation through fiduciary duty due to the business judgment rule. The latter often precludes a court from judging the substance of business decisions including executive pay decisions. In the seminal decision from the Delaware Court of Chancery (In Re Citigroup Inc. Shareholder Derivative Litigation) the Court allowed a motion to challenge the retirement package given to the Citigroup CEO Charles Prince upon his retirement in 2007. The Court, while granting the motions to dismiss by Citigroup, allowed a motion by the plaintiffs with regards to the corporate waste claim relating to the paying of Charles Prince's retirement package. ${ }^{62}$ Regarding the claims that were dismissed by the Court, arguments by the plaintiffs of an alleged breach of fiduciary duty relating to improper management of risk to Citigroup, and poor business decisions, were dismissed by the Court who gave deference to Citigroup in accordance with the "business

\footnotetext{
${ }^{60}$ Rineheart et al., supra note 47 at 107.

${ }^{61} I d$.

${ }^{62}$ Joseph W. Cooch, In re Citigroup Inc. Shareholder Derivative Litigation: In the Heat of Crisis, Chancery Court Scrutinizes Executive Compensation, 6 (1) BUS. \& TECH. L,169-170, (2011)
} 
judgment rule." 63 The operation of this rule, and the lack of statutory privilege granted to courts to analyze the content of business decisions means that, currently in the United States, fiduciary duty cannot stand as an effective instrument to control executive compensation.

The Dodd-Frank financial reforms passed in 2010 by the U.S Congress did not place any demands on the reasonableness of executive salary ${ }^{64}$ and directors continue to fail to ensure that, among other things, executive compensation is properly linked to the long-term performance of companies. ${ }^{65}$ Claw-back provisions could be instrumental to pay for long-term performance, but their effectiveness or utility in combating excessive executive compensation has not yet materialized. Section 954 of the Dodd-Frank Act instructs the Securities and Exchanges Commission (SEC) to institute a policy requiring that each national securities exchange institute rules that require listed companies have a claw-back policy. ${ }^{66}$ The proposed policy would require that where firms have issued financial restatements because of material noncompliance, then the firm must recover executive compensation (including stock options) that is based on erroneous data, that was paid out during the three year period prior to the restatement, or that is in excess of what would have been paid under the restatement. ${ }^{67}$ As of November 2015, the SEC has yet not acted under Dodd-Franks authority to issue the new rules, but they have been approved by the SEC, and are awaiting actual implementation. ${ }^{68}$

\footnotetext{
${ }^{63}$ In Re Citigroup Inc. Shareholder Derivative Litigation

${ }^{64}$ Mathieu, supra note , at 596 [confirm].

${ }^{65}$ See, e.g., Marc Goldstein, Mitigating Dysfunctional Deference Through Improvements in Board Composition and Board Effectiveness, 103 NW. U. L. REV. COLLOQUY 490, 499-500 (2009).

${ }^{66}$ Jessie M. Fried \& Nitzan Shilon, Excess-Pay Clawbacks, 36 JOURNAL OF CORPORATION LAW745, (2011).

${ }^{67} I d$.

${ }^{68}$ Maxwell Murphy, SEC Readies Clawback Rules for Punishing Bad Accountiny, THE WALL STREET JOURNAL, OCTOBER 12, 2015, http://www.wsj.com/articles/sec-readies-clawback-rules-for-punishing-badaccounting-1444694080.
} 
The Sarbanes-Oxley Act, passed in 2002, contains claw-back provisions, but are of more limited scope than the proposed Dodd-Frank claw-back provisions. The Sarbanes-Oxley Act issues claw-back requirements for publically traded companies. It allows the SEC to require that executive compensation (including profit from sale of stock) that is paid based on material noncompliance in a financial statement, specifically as a result of misconduct, with any financial reporting requirement, to be retrieved within 12 months of the erroneous financial statement. ${ }^{69}$ Differing from the Dodd-Frank Act, the Sarbanes-Oxley provisions allow the SEC to not only recover excess compensation, but all of the incentive pay issued to an executive. According to Jessie Fried and Nitzan Shilon, the Sarbanes-Oxley Act has been of limited efficacy, even with its more punitive scope than the Dodd-Frank with regards to which components of compensation that can be retrieved..$^{70}$ The law only allows the SEC alone the option of recovering the compensation, and only in the event of misconduct and because of financial constraints on the SEC and the difficulty in proving misconduct in litigation, it is rare that the provision is deployed by the SEC. ${ }^{71}$ Worth mentioning also, is the claw-back provisions that companies bailed out under TARP (Troubled Asset Relief Program) must legally abide by if compensation is issued under "materially inaccurate" financial statements. This provision however has been of no use in curbing excess compensation paid to the financial institutions bailed out; even where the Special Master for TARP Executive Compensation (Kenneth R. Feinberg) found that eighty per cent of the 1.7 billion dollars in the banking executive compensation he analyzed was unmerited, he nonetheless determined they were legal. ${ }^{72}$

\footnotetext{
${ }^{69}$ Fried \& Shilion, supra note 64 at 730.

${ }^{70} \mathrm{Id}$.

${ }^{71} I d$ at 731 .

${ }^{72}$ Charles W Murdock, The Dodd-Frank Wall Street Reform and Consumer Protection Act: What Caused the Financial Crisis and Will Dodd-Frank Prevent Future Crises?, 641284 (2011).
} 
Thus overall, while there are legal duties on the books to require claw-back provisions, they are not to the efficacy of the VorstAG's claw back provisions. Firstly, the American clawback provisions are all triggered in the event of firm non-compliance with financial disclosure requirements, while the VorstAG demands that claw-backs be utilized where the financial situation of a company deteriorates or where it would be unreasonable to allow the compensation to remain issued. Secondly, there is an issue of enforceability of the American provisions, specifically regarding the Sarbanes-Oxley provisions and those required by the TARP program. Those provisions have the potential to curb excessive executive compensation in large firms, but they have not been utilized to their potential. We will have to wait and see if the Dodd-Frank claw back provisions once instituted and enforced by the SEC, will be able to succeed where the other legislation has failed. However, currently, the extent to which American claw-back provisions impose a duty on directors to tie executive compensation with long-term sustainability is extremely limited, and it is evident that even where a legal duty theoretically exists, it is not operating to change executive behaviour because of a lack of enforcement. ${ }^{73}$

The regulatory structure in this regard is similar in Canada, where no federal or provincial regulations demand that executive compensation be reasonable in the same manner as Germany. ${ }^{74}$ There is, however, in Canada some court decisions which use the principle of fiduciary duty and the oppression remedy to limit outrageous remuneration by holding that the paying of such compensation, especially in dire economic circumstances, is contrary to shareholder interests. ${ }^{75}$ In BCE Inc. v. 1976 Debentureholders,${ }^{76}$ the Supreme Court of Canada, explaining the oppression

\footnotetext{
${ }^{73}$ Fried \& Shilon, supra note 64.

${ }^{74}$ Bo James Howell, Executive Fraud and Canada's Regulation of Executive Compensation, 39 (1) THE UNIVERSITY OF MIAMI INTER-AMERICAN LAW REVIEW118 (2007).

${ }^{75}$ Unique Broadband Systems Inc. (Re), 2013 ONSC 2953; and Koehnen, Oppression and Related Remedies

76 [2008] 3 SCR 560, 2008 SCC 69 (CanLII).
} 
remedy as set out in s. 241 of Canada Business Corporation Act, indicated that "Unfair prejudice" is generally seen as involving conduct less-offensive than "oppression" and examples of it include "paying directors' fees higher than the industry norm" ${ }^{77}$ Applying that criterion, several courts have found difficult to ascertain the industry norm and conduct a proper comparison between executives in order to establish whether a particular executive compensation is excessive. For example, in 1043325 Ontario Ltd. v. Jeck, ${ }^{78}$ the British Columbia Supreme Court struggled to determine the industry norm and noted "the importance of finding a proper comparator for determining whether the remuneration paid to a person running a business is excessive or reasonable." ${ }^{79}$ This criterion for determining the reasonableness or appropriateness of executive compensation does not include an executive-to-worker pay comparison, seems to disregard the international dimension of an 'industry norm' and may lead to legitimize excessive pay practices already existing within an industry.

More importantly, it also ignores the need to assess the long-term orientation of executive compensation for establishing its appropriateness or excessiveness. True, the Supreme Court of Canada in BCE Inc. v. 1976 Debentureholders ${ }^{80}$ has redefined the fiduciary duties of directors so that they may now consider the interests of multiple stakeholders and the long-term performance of their companies. Directors, in considering what is in the best interests of the corporation, "may look to the interests of, inter alia, shareholders, employees, creditors, consumers, governments and the environment to inform their decisions" ${ }^{\prime 1}$. Further, the Court indicated that the fiduciary duty of directors to the corporation "is not confined to short-term profit or share value. Where the

\footnotetext{
${ }^{77}$ At par. 93.

782014 BCSC 1197.

${ }^{79} \mathrm{Id}$. at paras. $128-130$.

${ }^{80}$ [2008] 3 SCR 560, 2008 SCC 69 (CanLII).

${ }^{81} I d$. at para. 40.
} 
corporation is an ongoing concern, it looks to the long-term interests of the corporation" ${ }^{\prime 2}$. It can then be argued that directors in exercising their fiduciary duties while making decisions such as setting executive compensation may look to the interest of multiple stakeholders and look to the long-term performance of their companies. Directors thus appear to have a duty to assess the extent to which executive compensation serves long-term firm performance. This is an implication that derives from BCE Inc. v. 1976 Debentureholders ${ }^{83}$ and will however need both clearer future pronouncements by Canadian courts and a significant compliance by corporate directors to more conclusively state that directors have a duty to tie executive compensation to the long-term performance of companies in Canada.

Increasingly, in the pension fund context, Canadian pension trustees are legally required to look to "longer-term, systemic concerns, such as intergenerational equity and sustainable development" and take into consideration "how their investment decisions will affect the stability of financial systems, the direction of the economy and the sustainability of our environment". ${ }^{84}$ As part of such long-term objectives, pension trustees should thus be required to make investment decisions that advance the long-term sustainability of the companies in which pension funds invest. To this end, Canadian pension trustees appear to be required to promote executive compensation policies that are instrumental to the long-term sustainability of the companies in which they invest and to the economy. This was clearly recommended by the European Commission in its 2009 Commission Recommendation on Remuneration Policies in the Financial Services Sector. ${ }^{85}$ The

\footnotetext{
${ }^{82}$ Id. at para. 38

${ }^{83}$ [2008] 3 SCR 560, 2008 SCC 69 (CanLII).

${ }^{84}$ Edward J. Waitzer \& Douglas Sarro, The Public Fiduciary: Emerging Themes in Canadian Fiduciary Law for Pension Trustees, 91 (1) CANADIAN BAR REVIEW 163, 165, 207-208 (2012).

${ }^{85}$ Commission Recommendation on Remuneration Policies in the Financial Services Sector, 2009/384/EC, April 30, 2009, OFFICIAL JOURNAL OF THE EUROPEAN UNION 15.5.2009, available at http://eur-lex.europa.eu/legalcontent/EN/TXT/PDF/?uri=CELEX:32009H0384\&from=EN.
} 
Commission recommended that financial institutions, including pension funds, should adopt remuneration policies that are aligned with long-term interests and sustainable growth of companies. ${ }^{86}$

There are no Canadian regulations that require companies to have or use claw-back provisions. Although their use has become more popular in Canada over the past two years, it is still entirely voluntary. ${ }^{87}$ Stephen C. Caywood argues that claw-back provisions can be a highly effective tool to incentivize long-term minded behaviour. When executives understand that the actions for which they receive bonuses or other variable compensation may have long-term negative and unsustainable consequences which may cause their compensation to be clawed back, they will be strongly incentivized to engage in wise long-term minded behaviour. ${ }^{88}$ The current non-mandatory nature of claw-backs further diminishes the ability of executive pay to promote long-term oriented compensation structure in Canada.

This lack of a clear legal duty to tie executive compensation to companies' long-term interest has been evident in the misalignment between executive pay practices and long-term firm performance in the years after the Supreme Court of Canada's 2008 decision in BCE Inc. v. 1976 Debentureholders ${ }^{89}$. While board of directors are reportedly increasing the use of incentives to

\footnotetext{
${ }^{86}$ Commission Recommendation on Remuneration Policies in the Financial Services Sector, (2009/384/EC), 30 April 2009, Official Journal of the European Union 15.5.2009, at L 120/25, section II, Art. 3.2.: "Remuneration policy should be in line with the business strategy, objectives, values and long-term interests of the financial undertaking, such as sustainable growth prospects, and be consistent with the principles relating to the protection of clients and investors in the course of services provided"; Art. 2.1: "A financial undertaking includes, but is not limited to, credit institutions, investment firms, insurance and reinsurance undertakings, pension funds and collective investment schemes." available at: http://eur-lex.europa.eu/legal-content/EN/TXT/PDF/?uri=CELEX:32009H0384\&from=EN

${ }^{87}$ John Tuzyk \& Faye Ghadani (January 2014), Canadian Clawbacks: Increasing But Still Voluntary. Blakes, available at http://www.blakes.com/English/Resources/Bulletins/Pages/Details.aspx?BulletinID=1867

${ }^{88}$ Steven C. Caywood, Wasting the Corporate Waste Doctrine: How the Doctrine Can Provide a Viable Solution in Controlling Excessive Executive Compensation, 109:1MICHIGAN LAW REVIEW 125-126, (2010).

${ }^{89}$ [2008] 3 SCR 560, 2008 SCC 69 (CanLII).
} 
align executive pay to long-term performance, ${ }^{90}$ the evidence to support such apparent pay practice is not yet systematic and the extent to which such long-term incentives are really being implemented is unclear. This problem has recently come to light in the context of a fresh opposition by Canadian large pension funds to Barrick Gold Corp's excessive executive pay structure in early 2015. ${ }^{91}$ The recent disclosure that Executive Chairman John Thornton was paid \$12.9 million in 2014 unleashed fresh complaints. Barrick has reportedly contended that "with its new pay structure, its senior leaders' personal wealth is directly tied to the company's long-term success". ${ }^{92}$ However, several proxy advisory firms, notably Institutional Shareholder Services (ISS) and Glass Lewis, have contended that "Thornton's pay is not clearly tied to any established and measurable long-term performance metrics. ${ }^{.93}$ Thus, it is unclear whether directors have a real duty to tie executive compensation to long-term performance in Canada and the few voluntary long-term pay practices that are reported do not seem to materialize. Unfortunately, the latter problem has become fairly common in many countries. Studies have found the firms claim to adopt long-term incentive plans for CEO compensation but they do not actually implement the plans. ${ }^{94}$ All of this

\footnotetext{
${ }^{90}$ Ken Hugessen \& Allison Lockett, CEO pay: the short and long-term of it, LISTED MAGAZINE, September 16, 2013available at: http://listedmag.com/2013/09/ceo-pay-the-short-and-long-term-of-it/ (reporting "shifts in weighting toward long-term incentives, and decreases in the weighting of stock options - all reflect a general attitude by today's boards to proceed with care given the still modest pace of recovery, actively manage risk, and take the long view. ... Median target total direct compensation for TSX60 CEOs increased by approximately 10\% in 2012 compared to 2011. Over the same period, base salaries increased 5\%, short-term incentive targets grew $9 \%$ and long-term incentive grants increased $14 \%$.... In terms of long-term incentive trends, the declining use of stock options continues. While almost $80 \%$ of TSX60 CEOs still received stock options in 2012, the weighting of options as a portion of CEO long-term incentives declined to $34 \%$ in 2012 from $48 \%$ in 2010 ...")

${ }^{91}$ Reuters Euan Rocha, Fresh opposition to Barrick Gold Corp's executive pay structure from Canada's largest pension fund manager, FINANCIAL POST April 24, 2015, http://business.financialpost.com/news/fp-street/freshopposition-to-barrick-gold-corps-executive-pay-structure-from-canadas-largest-pension-fund-manager

${ }_{92} I d$.

${ }^{93} I d$.

${ }^{94}$ See, e.g., James D. Westphal \& Edward J. Zajac, The Symbolic Management of Stockholders: Corporate Governance Reforms and Shareholder Reactions, 43:1 ADMINISTRATIVE SCIENCE QUARTERLY 127, 128 (1998).
} 
demonstrates that there is a need for a duty to tie executive compensation to long-term performance in Canada so that directors are legally required to align pay to the firm's long-term interest.

Thus, no statutory regulations or clear legal duties in Canada or the United States demand that executive compensation be appropriate or oriented towards long-term sustainable development in the way the VorstAG requires.

\section{DEVELOPING A DUTY OF DIRECTORS TO TIE EXECUTIVE COMPENSATION TO LONG-TERM FIRM PERFORMANCE IN LIBERAL MARKET ECONOMIES}

The need to pay executives for long-term performance has become a widely-held view and a fiduciary duty of directors to tie executive compensation to the long-term interest of companies is instrumental to that objective as our review of Germany's executive pay laws demonstrate. Such a duty sets an executive pay standard requiring a shift from short-termism to the long-term sustainability of the firm while legally moderating excessive executive compensation and controlling the power of managers to inflate their salaries. ${ }^{95}$

In determining executive pay for long-term performance, the latter should not solely be measured by increases in stock value over the long-run or long-term shareholder value as Romano

\footnotetext{
${ }^{95}$ Lucian Arye Bebchuk, Jesse M. Fried, \& David I. Walker, Managerial Power and Rent Extraction in the Design of Executive Compensation, 69 U. CHI. L. REV. 751, 754-55 (2002)., (arguing that managers use of their power to inflate their salaries and engage in rent extraction to pay themselves higher than they may deserve); LUCIEN BEBCHUK \& JESSE FRIED, PAY WITHOUT PERFORMANCE: THE UNFULFILLED PROMISE OF EXECUTIVE COMPENSATION (2004).
} 
and Bhagat advocate. ${ }^{96}$ Directors may be required to use of executive pay to promote not only the sustained growth and long-term profitability of their companies, but also steady improvements in the interests of multiple stakeholders involved in the long-term success of the company, including customers, employees and suppliers. ${ }^{97}$ This is of course difficult to quantify and will require a complex metric beyond the hard numerical data of stock value in order to measure future improvements in multiple stakeholders' interests. ${ }^{98}$ Simple metrics that include basic indicators of wage developments over time, investments in training and skill development and the environmental impact of corporate activity over the long-run may be more realistic and easily implementable. The assessment of this long-term multi-stakeholder performance should be set in a multi-year framework of, for example, three to five years. ${ }^{99}$

\footnotetext{
${ }^{96}$ Sanjai Bhagat \& Roberta Romano, Reforming Executive Compensation: Simplicity, Transparency and Committing to the Long-Term, (October 21, 2009) YALE LAW \& ECONOMICS RESEARCH PAPER, No. 393, (2009) (arguing that "Executive compensation reform should lead to policies that are simple, transparent, and focused on creating and sustaining long-term shareholder value"), available at SSRN: http://ssrn.com/abstract=1506742 or http://dx.doi.org/10.2139/ssrn.1506742; Sanjai Bhagat \& Roberta Romano, Reforming Executive Compensation: Focusing and Committing to the Long-Term, 26 YALE J. ON REG. 359, 359 (2009) (arguing that compensation arrangements should be "focused on creating and sustaining long-term shareholder value"). See also Stephen M. Bainbridge, Director Primacy: The Means and Ends of Corporate Governance, 97 NW. U. L. REV. 547, 573, (2003) (arguing that directors are "obliged to make decisions based solely on the basis of long-term shareholder gain"); John H. Matheson \& Brent A. Olson, Corporate Cooperation, Relationship Management, and the Trialogical Imperative for Corporate Law, 78 MINN. L. REV. 1443, 1444, 1484 (1994) (claiming that managers should focus their efforts on maximizing value for long-term shareholders).

97 LYNN STOUT, SHAREHOLDER VALUE MYTH: HOW PUTTING SHAREHOLDERS FIRST HARMS INVESTORS, CORPORATIONS, AND THE PUBLIC 110-11, (2012) (" $[\mathrm{t}] \mathrm{o}$ build enduring value, managers must focus on the long term as well as tomorrow's stock quotes, and must sometimes make credible if informal commitments to customers, suppliers, employees, and other stakeholders whose specific investments contribute to the firm's success"). The European Commission has recommended that the financial institutions adopt executive remuneration policies that promote their long-term interest and the protection of their clients. See Commission Recommendation on Remuneration Policies in the Financial Services Sector, 384, , OFFICIAL JOURNAL OF THE EUROPEAN UNION 15, 5, (2009), at L 120, 25, Section II, Art. 3, 2: : "Remuneration policy should be in line with the business strategy, objectives, values and long-term interests of the financial undertaking, such as sustainable growth prospects, and be consistent with the principles relating to the protection of clients and investors in the course of services provided", available at http://eur-lex.europa.eu/legal-content/EN/TXT/PDF/?uri=CELEX:32009H0384\&from=EN.

${ }^{98}$ Larry D. Thompson, The Responsible Corporation: Its Historical Roots and Continuing Promise, 29 NOTRE DAME JOURNAL OF LAW, ETHICS \& PUBLIC POLICY 199, 229, (2015)

${ }^{99}$ Similar to the recommendation of the European Commission. See Commission Recommendation on Remuneration Policies in the Financial Services Sector, (2009/384/EC), 30 April 2009, consideration (14): “...The assessment of performance should be set in a multi-year framework, for example of three to five years, in order to ensure that the assessment process is based on longer term performance..."; Article 5.2.: "The assessment of performance should be set in a multiyear framework in order to ensure that the assessment process is based on longer term performance and that the actual
} 
In factoring employees' interest in long-term firm sustainability, directors should also tie executive compensation to steady improvements in working conditions including sustainable wages, job security, training and skill development, healthy and safe work environments as well as in employee productivity, job satisfaction, innovation and loyalty. Needless to say, these conditions and economic goals associated with employee welfare and performance are vital for the short-term success and the long-term sustainability of companies. Healthy, skillful, productive, fairly satisfied and committed workers is a critical factor in creating productive, innovative and growing companies in the short and long-term. ${ }^{100}$ The 2012 German Sustainability Code (GSC) sheds further light on the possible metric of employees' interest that directors can use when setting executive compensation for long-term firm sustainability. Section 8 of the German Sustainability Code recommends that companies develop executive remuneration policies that are geared towards the larger objective of sustainability. ${ }^{101}$ This is important because the success and longterm sustainability of companies also depend on the contribution of multiple stakeholders (including employees) whose interests are precisely promoted by sustainability objectives. Thus, the assessment of pay for long-term firm sustainability should also be informed by expectations of sustainability as applied to companies. The GSC considers employee rights and diversity as an important part of sustainability. As such, the GSC recommends:

Employee Rights and Diversity

payment of bonuses is spread over the business cycle of the company", Official Journal of the European Union 15.5.2009, available at http://eur-lex.europa.eu/legal-content/EN/TXT/PDF/?uri=CELEX:32009H0384\&from=EN. Other authors have suggested a two-to-four year framework from a shareholder value perspective of long-term executive pay. See, e.g., Bhagat \& Romano, Reforming Executive Compensation: Simplicity, Transparency and Committing to the Long-Term, supra note ("we suggest that incentive compensation plans should consist only of restricted stock and restricted stock options, restricted in the sense that the shares cannot be sold nor the options exercised for a period of at least two to four years after an individual resignation or last day in office").

${ }^{100}$ LYNN STOUT, SHAREHOLDER VALUE MYTH, supra note , at 110-11.

101 The German Sustainability Code, supra note, at 8. 
14. The company reports on how, on the basis of both nationally and internationally recognized standards, it works towards observing employee rights and also towards promoting employee involvement.

15. The company discloses in what way it has implemented national and international processes in order to promote equal opportunities, health and safety, integration of migrants and people with disabilities, fair pay as well as a work-life balance and also in order to suppress all forms of discrimination, e.g. based on ethnic background, gender, religion/ideology, age, or sexual identity.

16. The company discloses what steps it has taken to promote the general employability of all employees and to adapt it to demographic change. ${ }^{102}$

The GSC goes even further and proposes a number of key indicators of employees' rights that should be considered in the assessment of companies' contribution to sustainability. The GSC suggests to measure rates of injury, occupational diseases, absenteeism, work-related fatalities, education, expenses and hours of training, counselling, prevention, risk-control, existing health services, composition of governance bodies (including a breakdown of employees per category according to gender, age group, minority group membership, and other indicators of diversity), number of incidents of discrimination and actions taken, percentage of female employees in relation to total employees and percentage of female employees in senior positions. ${ }^{103}$

The inclusion of improvements in long-term worker welfare in the metrics of the long-term performance of companies is not only economically sound but it has also been legally required as part of the fiduciary duties of directors. As demonstrated in our review of the German corporate law, the members of the Supervisory Board are legally required to determine the compensation of the members of the Management Board with the aim of the company's sustainable development (s. 87 of the $A k t G$ ) and shall consider the relationship between the compensation of the Management Board and the staff overall "particularly in terms of its development over time" (s.

\footnotetext{
102 The German Sustainability Code, supra note, at 12.

103 The German Sustainability Code, supra note, at 13.
} 
4.2.2. Corporate Governance Code). Thus, Supervisory Board members must consider the interests of workers when setting executive compensation for long-term performance. German codetermination with its two-tier board system further secures that workers' interest is taken into account when directors tie executive compensation to long-term firm performance. While the members of the Supervisory Board are elected by the shareholders at the General Meeting, employees are also represented in the Supervisory Board and control one third or one half of the seats in enterprises having more than 500 or 2,000 employees respectively. ${ }^{104}$ Employees are then influential in the Supervisory Board decisions including the determination of long-term oriented executive compensation and will subsequently tend to promote firm sustainability and a metric thereof that includes their interest in fair and sustainable working conditions. This is consistent with Germany's co-determination system that has historically been committed to promote multiple stakeholders' interest and the VorstAG is embedded in such stakeholder culture and thus requires that long-term executive compensation considers the interests of not only shareholders but also of employees, creditors, suppliers and other non-shareholder stakeholders. ${ }^{105}$

The duty of directors to tie executive compensation to the long-term interest of companies, including the consideration of employees' interest, is becoming apparent in some liberal market economies. A notable example is Section 172 of UK's Companies Act 2006 which requires directors to promote the success of the company giving consideration to the long-term and the impact on multiple stakeholders' interest, including employees. Section 172 reads as follows:

172. Duty to promote the success of the company

(1)A director of a company must act in the way he considers, in good faith, would be most likely to promote the success of the company for the benefit of its members as a whole, and in doing so have regard (amongst other matters) to-

\footnotetext{
${ }^{104}$ Introduction, The Deutscher Corporate Governance Kodex, THE GERMAN CORPORATE GOVERNANCE CODE1,, (2015).

${ }^{105}$ Mathieu, supra note, at 586.
} 
(a) the likely consequences of any decision in the long term,

(b) the interests of the company's employees,

(c) the need to foster the company's business relationships with suppliers, customers and others,

(d) the impact of the company's operations on the community and the environment,

(e) the desirability of the company maintaining a reputation for high standards of business conduct, and

(f) the need to act fairly as between members of the company. ${ }^{106}$

It follows that directors have a duty to promote the short and long-term success of companies and, when it comes to executive compensation decisions, directors must ensure that executive pay also serves that success. In doing so, directors must inter alia have regard to employees' interests. While these implications of Section 172 appear to be clear, there are, however, growing concerns that directors are not tying executive pay to the long-term performance of companies in the $\mathrm{UK}^{107}$ and employees' interests do not seem to be included in such decisions.

Some form of involvement of stakeholders in long-term executive pay determination is ideal to ensure that the assessment of the long-term sustainability of companies captures improvements in stakeholders' interest. In particular, in liberal market economies with the absence of industrial citizenship, ${ }^{108}$ introducing employees' say on pay is critical. It is desirable that employees are given real opportunities both to communicate their long-term interests and to monitor the extent to which executive compensation promotes the long-term sustainability of companies including their interests. This may be an imperative in light of the current and likely

106 Companies Act 2006, c. 46 Part 10 Chapter 2 The general duties, Section 172, http://www.legislation.gov.uk/ukpga/2006/46/section/172

107 See, e.g., Accounting Watchdog Pushes Long-Term Pay Rules, THE TELEGRAPH, (2014) http://www.telegraph.co.uk/finance/newsbysector/banksandfinance/10783553/Accounting-watchdog-pushes-longterm-pay-rules.html

108 VARIETIES OF CAPITALISM: THE INSTITUTIONAL FOUNDATIONS OF COMPARATIVE ADVANTAGE (Peter Hall \& David Soskice eds., 2001). 
increasing opposition of short-term oriented shareholders and self-serving directors and officers ${ }^{109}$ to long-term performance and its responsiveness to stakeholders' interest and employees' interest in particular. ${ }^{110}$ Even when long-term executive compensation plans are apparently adopted, companies are reluctant and do not effectively execute them. This current problem appears to be an old practice. Studies done in 1990s show how long-term oriented compensation plan are often symbolically adopted by corporations, to the positive reaction of the market, without those plans actually being implemented. ${ }^{111}$ Implementing a duty to tie executive compensation to long-term performance may be challenging in the presence of strong shareholder primacy culture that is still prevalent in countries like the US and Canada.

The benefits of an effective implementation of a fiduciary duty to tie executive compensation to the long-term sustainability of companies that is sensitive to non-shareholder stakeholders' interest would be considerable and would not be restricted to the company. It is likely to have a significant positive impact on multiple stakeholders, societal equality and the sustainability of the economy. This is important because it will not only secure corporate success and benefit investors, but it will also help protect employees' interest in job security, fair and sustainable wages and secured pension, create more stable economies and avoid citizens

\footnotetext{
${ }^{109}$ See, e.g., Bebchuk, Fried, \& Walker, supra note 87, at 754-55, (arguing that managers use of their power to inflate their salaries and engage in rent extraction to pay themselves higher than they may deserve); BEBCHUK \& FRIED, supra note 87.

${ }^{110}$ Katharine V. Jackson, Towards a Stakeholder-Shareholder Theory of Corporate Governance: A Comparative Analysis, 7 HASTINGS BUSINESS LAW JOURNAL 309 (2011) (noting that "although management, labor and other stakeholders may enjoy a common interest in the long-term sustainability of corporations, their shareholders may not. As a result, corporate boards began to make increasingly short-term decisions ..."); CFA Centre for Financial Market Integrity and Business Roundtable, Institute for Corporate Ethics, Breaking the Short-Term Cycle (2006) 2006 CFA Institute (finding that "The obsession with short-term results by investors, asset management firms, and corporate managers collectively leads to the unintended consequences of destroying long-term value, decreasing market efficiency, reducing investment returns and impeding efforts to strengthen corporate governance"). See also CFA Institute, Visionary Board Leadership - Stewardship for the Long Term, (2012) CFA Institute.

${ }^{111}$ Westphal \& Zajac, supra note .
} 
subsidizing periodic corporate failures, ${ }^{112}$ excessive executive pay and the wealth accumulation plans of an elite shareholder class.

Further research to analyze the prospects of a duty to tie executive compensation to the long-term sustainability of companies is needed. It would be important, for example, to discuss the content of variable compensation instruments and the extent to which such instruments effectively serve the long-term interest of companies and whether they are able to capture multiple stakeholders' interests including employees' interest. Furthermore, the enforcement and impact of such a duty are likely to face significant barriers from short-term oriented shareholders and selfserving directors and officers and it is important to identify obstacles and explore conditions that would facilitate an effective implementation of such a duty. For example, it would be possible to counter resistance to such a duty through the increased involvement of long-term oriented shareholders who have a specific interest in the paying of long-term oriented compensation. Specifically, institutional investors such as union and pension fund shareholders could prove to be a key ally in helping the consolidation of any substantive regulatory reform of the kind that is being proposed. ${ }^{113}$ These types of investors could counter the voice of other more short-term oriented investors and stakeholders, and through a 'say on pay' vote, the voice of these long-term oriented shareholders could have an appropriate outlet to enforce their interests and concerns. With the

\footnotetext{
112 Even authors that advocate pay for long-term performance that is mainly measured in terms of long-term shareholder value have highlighted the importance of long-term executive compensation reforms for preventing the waste of public resources in bailing out failing companies. See Bhagat \& Romano, Reforming Executive Compensation: Simplicity, Transparency and Committing to the Long-Term, supra note (claiming that "By reducing management incentive to take on unwarranted risk, our proposal would therefore also decrease the probability that public resources will be dissipated in bailouts of financial firms, particularly those deemed by public officials as "too big to fail."'”)

${ }^{113}$ Yonca Ertimur, et al, Shareholder Activism and CEO Pay, 24 (2) REVIEW OF FINANCIAL STUDIES (2011). For example, CalPERS, the largest pension fund in the US, has indicated that it has adopted principles that reflect each Board member's commitment to a long-term view of the needs of beneficiaries and system participants, among other things. See CalPERS, http://www.calpers.ca.gov/eip-docs/about/organization/board/02152012-boardgovernance.pdf.
} 
current realities of corporate excess and wealth inequality, and indications that the regulatory structure which allowed the 2008 recession have not been significantly altered to prevent another major crash, it is of utmost necessity that comprehensive reform initiatives, such as ones inspired by the VorstAG are seriously considered and analyzed thoroughly for their potential ability to provide a more sound and sustainable corporate regulatory regime.

\section{CONCLUSION}

This paper has discussed the merits of a fiduciary duty of directors to tie executive compensation to the long-term sustainability of the firm drawing on the insights of a comparative study of the regulation of executive pay in Germany, the US and Canada. While the duty to tie executive pay to long-term performance is not clearly established in the US and Canada and is largely a voluntary practice, Germany introduced the 2009 German VorstAG (the "Act on the Appropriateness of Management Board Remuneration) which clearly requires Supervisory Boards to set executive compensation with aim of the sustainable growth of companies. Building on the lessons that can be drawn from the 2009 German VorstAG, it was argued that directors should be legally required to tie executive compensation to the long-term firm sustainability that in turn requires a metric that balances sustained growth and long-term shareholder value with steady improvements in the interests of multiple stakeholders involved in the long-term success of the company. The paper focused on employees' long-term interest and its inclusion in the assessment of the long-term sustainability of companies. It was further argued that, in liberal market economies, employees' 'say on pay' should be given significant consideration as it will allow employees to communicate their interests in order both to incorporate them in the metric of long- 
term firm sustainability and to control the likely opposition from short-term oriented shareholders and self-serving directors and officers. The benefits of this proposal are significant as it will ultimately protect shareholders and employees' interest in job security, fair and sustainable wages and secured pension while creating more stable economies and avoiding citizens subsidizing periodic corporate failures, excessive executive pay and the wealth accumulation plans of an elite shareholder class.

It is important to further explore the content and implementation of the duty to tie executive compensation to long-term firm sustainability in future research. Developing a more detailed metric of long-term firm sustainability that captures multiple stakeholders' interests and compensation instruments that are consistent with that metric appears to be the next step in this line of research. Furthermore, the enforcement and impact of such a duty are likely to face significant barriers from short-term oriented shareholders and self-serving directors and officers and it is thus critical to identify obstacles and explore conditions that would facilitate an effective implementation of such a duty. 